\title{
PENGARUH KOMPENSASI, BUDAYA ORGANISASI, GAYA KEPEMIMPINAN DAN DISIPLIN KERJA TERHADAP KEPUASAN KERJA KARYAWAN RESTORAN SARI LAUT NELAYAN MEDAN
}

\author{
Shamir Hasyim Syarif ${ }^{1)}$ dan Nirmadarningsih Hiya ${ }^{2)}$
}

\author{
${ }^{1)}$ Universitas IBBI dan ${ }^{2)}$ Universitas Pembinaan Masyarakat Indonesia \\ email: Shamir.hasyim@gmail.com,dan nirmadarningsih.hiya@ gmail.com
}

\begin{abstract}
Tujuan penelitian ini adalah untuk mengetahui pengaruh kompensasi, budayaorganisasi, gaya kepemimpinan dan disiplin kerja terhadap kepuasan kerja karyawan Restoran Sari Laut Nelayan Medan. Metode yang digunakan dalam penelitian ini adalah dengan metode deskriptif, jenis penelitian ini adalah data kuantitatif, data primer yang diperoleh melalui kuesioner. Populasi pada penelitian ini adalah seluruh karyawan pada perusahaan sebanyak 110 karyawan. Sampel yang digunakan adalah teknik sampel jenusdimana seluruh populasi akan dijadikan sebagai sampel. Teknik analisis yang digunakan adalah analisis linier berganda. Hasil pengujian yang menunjukkan bahwa secara parsial maupun simultan variabel kompensasi, budaya organisasi, gaya kepemimpinan dan disiplin kerja berpengaruh positif dan signifikan terhadap kepuasan kerja karyawan. Kesimpulan penelitian ini adalah baik secara parsial dan simultan, variabel kompensasi, budaya organisasi, gaya kepemimpinan dan disiplin kerja berpengaruh positif dan signifikan terhadap kepuasan kerja karyawan Restoran Sari Laut Nelayan Medan.
\end{abstract}

Kata Kunci: Kompensasi, Budaya Organisasi, Gaya Kepemimpinan, DisiplinKerja, Kepuasan

\section{Pendahuluan}

Sumber Daya Manusia merupakan penggerak utama dalam suatu organisasi. Kunci sukses suatu perusahaan bisa terletak pada sumber daya manusia yaitu sebagai inisiator, pemberi tenaga kreativitas, dan usaha mereka kepada organisasi untuk meningkatkan kemampuan perubahan organisasi secara terusmenerus (Handoko, 2003). saat ini sumber daya manusia menjadi salah satu unsur yang sangat penting bagi kehidupan suatu perusahaan, dimana majumundurnya suatu perusahaan salah satu faktornya bisa ditentukan oleh sumber daya manusia yang dimiliki. Dengan memiliki sumber daya manusia yangterampil dan mampu bersaing dengan sumber daya manusia perusahaan kompetitor, bisa menjadi salah satu penentu kemajuan suatu perusahaan.Kualitas organisasi bergantung pada kualitas orang-orang yang berada didalamnya (Robbins, 2010). Kepuasan kerja adalah keadaan emosional yang menyenangkan atau tidak menyenangkan dimana para karyawan memandang pekerjaannya. Kepuasan kerja terjadi melalui sikap karyawan mengenai pekerjaannya yang ditunjukkan dari perasaan nyaman, senang, merasa dihargai, dan lainnya selama bekerja di perusahaan. Kepuasan kerja tidak tampak serta nyata tetapi dapat diwujudkan dalam suatu hasil pekerjaan (Sunyoto, 2010). Selain itu, dapat memicu karyawan untuk mengundurkan diri (turnover) dariperusahaan (Kartika, 2010).

Berdasarkan hasil observasi awal yang peniliti lakukan dengan mewawancarai karyawan yang telah lam bekerja disana, kinerja perusahaan dinyatakan cukup baik selama masa perkembangannya namun pada 5 tahun terakhir ini mulai terlihat bahwa terdapat sedikit ketidakstabilan pada penjualan perusahaan. Restoran Sari Laut Nelayan adalah perusahaan yang bergerak dibidang makanan terkhususnya untuk makanan seafood yang berdiri sejak tahun 1995. Perusahaan ini berpusat di Jln. Putri Merak Jingga No. 17 a dengan areal restoran yang 
sangat luas. Selama 5 tahun terakhir penjualan perusahaan mengalami ketidak stabilan dimana pada tahun tertentu mengalami kenaikan dan terkadang mengalami penurunan. Namun ada satu hal yang pasti yaitu penjualan perusahaan selama 5 tahun terakhir masih belum terlihat mencapai target yang diberikan padahal target yang diberikan tersebut masih tetap sama selama 5 tahun tanpa adanya kenaikan yang ditentukan perusahaan. Berdasarkan observasi awal yang peniliti lakukan, bahwa terjadi penurunan kualitas kerja dari karyawan.

Faktor awal yang diduga memiliki pengaruh adalah kompensasi yang diberikan masih terhitung cukup rendah. Berdasarkan observasi awal yang peneliti lakukan bahwa kompensasi yang diberikan perusahaan lebih rendah dari perusahaan lain sehingga karyawan merasa bahwa kinerja yang mereka berikan dengan baik terasa tersia-sia kan. Masalah lain yang menyebabkan tingkat kepuasan kerja karyawan yang menurun sehubungan dengan gaji, adanya ketidakpuasan karyawan yang banyaknya tuntutan pekerjaan sehungga tidak sesuai dengan upah yang diterima dan karyawan menginginkan sistem upah serta kebijakan promosi harus adil, tidak meragukan dan segaris dengan pengharapannya.

Kompensasi mempunyai pengaruh yang sangat penting dalam meningkatkan semangat kerja karyawan, seperti yang diketahui kompensasi merupakan seluruh balas jasa yang diterima oleh karyawan dari perusahaan sebagai imbalan atas pekerjaan mereka di perusahaan dalam bentuk finansial atau nonfinansial dan menjadi tujuan utama karyawan. Kompensasi mampu mengikat karyawan supaya tidak keluar dari perusahaan. Robbins (dalam Putra dkk 2014) semakin besar kompensasi yang diberikan oleh perusahaan maka semangat kerja karyawan dalam melaksanakan kewajibannya akan semakin tinggi, sebaliknya bila kompensasi yang diberikan oleh perusahaan kecil semangat kerja karyawan dalam melaksanakan kewajibannya akan semakin rendah.

Budaya Organisasi dapat mempengaruhi cara bekerja dan berperilaku karyawan pada organisasi yang diterapkan, maka dapat membuat karyawan bekerja dengan nyaman, energik dan memperoleh kepuasan kerja yang diharapkan. Namun pada kenyataannya masih banyak karyawan yang mengabaikan peraturan perusahaan serta norma-norma perusahaan seperti tidak menjaga keamanan saat bekerja, rendah nya tingkat keramahan sesama karyawan di perusahaan tersebut terutama antara admin dengan pelayan restoran.

Faktor lain yang juga mempunyai peran dalam upaya meningkatkan kepuasan kerja karyawan adalah Gaya Kepemimpinan. Menurut Gorda (2004) banyak faktor yang dapat mempengaruhi kepuasan kerja karyawan, dimulai dari kepemimpinan yang diterapkan di dalam perusahaan. Kemampuan pemimpin untuk mempengaruhi orang lain akan memberikan motivasi tersendiri bagi karyawan untuk melakukan sesuatu guna mencapai tujuan yang diinginkan. Keseluruhan rangkaian hubungan baik yang bersifat formal maupun informalantara atasan dengan bawahan, atasan dengan atasan, antara bawahan dengan bawahan lainnya akan membentuk hubungan yang harmonis anatara pemimpin dengan karyawan akan berdampak pada meningkatnya kinerja dan semangat kerja karyawan. Menurut Zaccro dkk (2004) sifat kepemimpinan yang seharusnya seperti kecerdasan, yakni kemampuan verbal yang kurang kuat, kurangnya kemampuan bersosialisasi juga merupakan salah satu factor penentu kepuasan karyawan terhadap pemimpin.

Faktor lain yang digunakan untuk melihat kepuasan kerja karyawan adalah Disiplin Kerja. dimana disiplin kerja adalah sikap mental yang tercermin dalam perbuatan atau tingkah laku seseorang, kelompok masyarakat berupa ketaatan (obedience) terhadap peraturan, norma yang berlaku dalam masyarakat. Disiplin kerja dapat diperlihatkan dalam bentuk memenuhi dan menaati peraturan yang berlaku serta bertanggung jawab dalam melaksanakan pekerjaan sesuai yang ditetapkan oleh perusahaan. Namun pada kenyataan nya masih terdapat karyawan yang mengabaikan peraturan yang ada di perusahaan yaitu tidak hadir tanpa pemberitahuan kepada atasan sehingga target kerja yang telah di berikan oleh karyawan harus di kerjakan di hari tersebut. data yang diteliti ternyata kondisi pada Restoran Sari Laut Nelayan di jumpai masih adanya pegawai yang sering terlambat masuk kerja.

\section{Literatur Review Kompensasi}

Hasibuan (2016) kompensasi adalah semua pendapatan yang berbentuk uang, barang langsung atau tidak langsung yang diterima karyawan sebagai imbalan atas jasa yang diberikan kepada perusahaan. Sinambela (2017) kompensasi merupakan salah satu alasan dan motivasi utama mengapa karyawan bekerja. Karyawan menggunakan seluruh pengetahuan, keterampilan, tenaga, waktu, serta komitmennya bukan semata-mata ingin membaktikan atau mengabdikan diri kepada perusahaan., melainkan tujuan lain yang ingin diraihnya yaitu mengharapkan imbalan atau balas jasa atas kinerja dan kepuasan kerja yang telah dihasilkan oleh karyawan. Menurut Siagian (2015:253) 
"Kompensasi yang diterima atas jasa yang diberikan kepada organisasi harus memungkinkan untuk mempertahankan harkat dan martabat pekerjanya sebagai insan yang terhormat serta memungkinkan untuk mempertahankan taraf hidup yang wajar dan layak hidup tanpa menggantungkan pemenuhan berbagai jenis kebutuhan hidupnya kepada orang lain".

Berdasarkan pendapat para ahli diatas, maka dapat disimpulkan bahwa kompensasi merupakan total dari semua hadiah yang diberikan organisasi kepada karyawan sebagai imbalan atas jasa mereka dan menjadi hal yang menarik, mempertahankan dan memotivasi karyawan agar memberikan tenaga dan pikiran yang terbaik bagi perusahaan

\section{Budaya Organisasi}

Siregar (2018) budaya organisasi adalah sistem keyakinan, nilai-nilai dan norma untuk menjadi pedoman terhadap tingkah laku anggota organisasi agar dapat mengatasi masalah yang terjadi baik secara eksternal maupun internal. Putrandi (2017) budaya organisasi merupakan kegiatan yang berkaitan dengan membagikan nilai-nilai dan kepercayaan yang mendasari identitas suatu perusahaan. Menurut Candra (2019) budaya organisasi adalah seperangkat keyakinan yang dibagikan dan diterima secara personal serta dijadikan pegangan oleh suatu kelompok agar dapat menyesuaikan dengan lingkungan yang beragam. Menurut Hartatik (2017) "Budaya organisasi adalah kebiasaankebiasaan yang dilakukan pada sebuah organisasi yang mewakili norma-norma perilaku yang kemudian diikuti oleh anggotanya.

Dari penjelasan di atas, peneliti menyimpulkan bahwa budaya organisasi merupakan sebuah penerapan kebiasaankebiasaan, nilai, norma dan kepercayaan yang dijadikan pedoman terhadap tingkah laku anggota organisasi yang diterima dan dijadikan sebagai dasar pegangan oleh suatu kelompok.

\section{Gaya Kepemimpinan}

organisasi atau kelompok kerja tertentu, sifat dari tugas atau kerja kelompok, tekanan waktu, dan bahkan faktor-faktor lingkungan yang dapat mempengaruhi sikap anggota organisasi terhadap wewenang. Menurut Feriyanto, dkk. (2015) perbedaan gaya kepemimpinan dalam organisasi akan mempunyai pengaruh yang berbeda pula pada partisipasi individu dan perilaku kelompok.

Berdasarkan pendapat beberapa para ahli di atas, maka dapat peneliti simpulkan bahwa pemilihan gaya kepemimpinan dapat memberikan pengaruh yang berbeda dalam perusahaan karena dapat meningkatkan komitmen para karyawan untuk bekerja lebih giat dan mempengaruhi sikap anggota organisasi dalam bekerja.

\section{Disiplin Kerja}

Menurut Hasibuan (2016) kedisiplinan adalah kesadaran dan kesediaan seseorang menaati semua peraturan perusahaan dan norma-norma sosial yang telah ditetapkan. Sutrisno (2016), disiplin menunjukkan suatu kondisi atau sikap hormat yang ada pada diri karyawan terhadap peraturan dan ketetapan yang telah ditentukan oleh perusahaan. Menurut Siagian (2015), disiplin adalah suatu bentuk pelatihan yang berusaha memperbaiki dan membentuk pengetahuan, sikap dan perilaku karyawan sehingga para karyawan tersebut secara sukarela berusaha bekerja sama secara kooperatif dengan para karyawan. Menurut Hartatik (2017) kedisiplin merupakan fungsi manajemen sumber daya manusia yang terpenting dan kunci terwujudnya tujuan. Sebab, tanpa adanya disiplin yang baik, sulit terwujud tujuan yang maksimal. Kedispilinan adalah keinginan dan kesadaran untuk menaati peraturan-peraturan perusahaan dan normanorma sosial.

\section{Kepuasan Kerja}

Menurut Hasibuan (2016), kepuasan kerja adalah sikap emosional yang menyenangkan dan mencintai pekerjaannya. Sikap ini dicerminkan oleh moral kerja, kedisiplinan, dan prestasi kerja. Kepuasan kerja dinikmati dalam pekerjaan, luar pekerjaan dan kombinasi dalam dan luar pekerjaan. Menurut Siagian (2015), meskipun kepuasan mempunyai konotasiyang beraneka ragam, namun demikian tetap relevan untuk mengatakan bahwa kepuasan kerja merupakan suatu cara pandang seseorang baik yang bersifat positif maupun negatif tentang pekerjaannya. Menurut Badeni (2017), kepuasan kerja karyawan merupakan salah satu elemen yang cukup penting dalam organisasi. Hal ini disebabkan kepuasan kerja personel organisasi dapat mempengaruhi perilaku kerja seperti malas, rajin, produktif, dan lain-lain atau mempunyai hubungan dengan beberapa jenis perilaku yang sangat penting dalam organisasi.

Berdasarkan pendapat ahli diatas, disimpulkan bahwa kepuasan kerja merupakan suatu sikap emosional yang menyenangkan dan mencintai pekerjaannya dan elemen yang cukup penting dalam organisasi yang menjadi cara 
pandang seseorang baik bersifat negatif maupun positif dalam pekerjaannya.

\section{Metodelogi}

Penelitian ini menggunakan metode kuantitatif. Populasi penelitian yang akan digunakan dalam penelitian adalah seluruh karyawan pada Restoran Sari Laut Nelayan yang berjumlah 110 karyawan.

\section{Uji Validitas}

"Pengujian signifikansi dilakukan dengan kriteria menggunakan rtabel pada tingkat signifikansi 0,05 dengan uji 2 sisi. Jika nilai positif dan $r_{\text {hitung }}>r_{\text {tabel }}$, item dapat dinyatakan valid dan sebaliknya Jika nilai $r_{\text {hitung }}<r_{\text {tabel }}$, item dinyatakan tidak valid.

\section{Uji Realibilitas}

Secara umum pengambilan keputusan untuk uji reliabilitas dapat menggunakan kategori sebagai berikut :

1. Cronbach's alpha $<0,6=$ reliabilitas buruk.

2. Cronbach's alpha $0,6-0,79=$ reliabilitas diterima.

3. Cronbach's alpha $0,8=$ reliabilitas baik

\section{Uji Normalitas}

Uji normalitas residual digunakan untuk menguji apakah nilai residual yang dihasilkan dari regresi terdistribusi secara normal atau tidak. Model regresi yang baik adalah memiliki residual yang terdistribusi secara normal. Beberapa metode uji normalitas yaitu dengan melihat penyebaran data pada sumber diagonal pada grafik Normal Probability Plot of Regression atau dengan uji One Sample Kolmogorov Smirnov. Berikut ini pembahasannya.

\section{Uji Multikolinieritas}

Multikolinieritas adalah keadaan pada model regresi ditemukan adanya korelasi yang sempurna atau mendekati sempurna antarvariabel independen dimana model regresi yang baik seharusnya tidak terjadi korelasi sempurna atau medekati sempurna diantara variabel bebas. Priyatno (2018), "Metode uji multikolinieritas yang umum digunakan yaitu dengan melihat nilai Tolerance dan Variance Inflation Factor (VIF) pada model regresi dimana nilai VIF kurang dari 10 dan mempunyai angka Tolerance lebih dari 0,1

\section{Uji Heteroskedastisitas}

Priyatno (2018) heteroskedastisitas adalah keadaan dimana dalam model regresi terjadi ketidaksamaan varian dari residual pada satu pengamatan ke pengamatan lainnya dimana model yang regresi yang baik adalah tidak terjadi heteroskedastisitas.. Untuk pengujian kedua adalah pengujian Glejser mengusulkan untuk meregres nilai absolut residual terhadap variabel independen apabila probabilitas signifikansinya di atas tingkat

\section{Analisis Regresi Linier Berganda}

Menurut Sunyoto (2014) analisis regresi berganda untuk mengetahui pengaruh dua atau lebih variabel bebas $\left(X_{1,2,3, \ldots n}\right)$ terhadap variabel terikat (Y)". Tujuan digunakan analisis regresi berganda pada penelitian ini adalah untuk mengetahui seberapa besar pengaruh kompensasi, budaya organisasi, gaya kepemimpinan dan disiplin kerja terhadap kepuasan kerja karyawan pada Restoran Sari Laut Nelayan:

$$
Y=a+b_{1} X_{1}-b_{2} X_{2}+b_{3} X_{3}+b_{4} X_{4}+e
$$

$$
\begin{aligned}
& \text { Keterangan : } \\
& Y=\text { Kepuasan Kerja } \\
& X_{1}=\text { Kompensasi } \\
& X_{2}=\text { Budaya Organisasi } \\
& X_{3}=\text { Gaya Kepemimpinan } \\
& X_{4}=\text { Disiplin Kerja } \backslash \\
& a=\text { Konstanta } \\
& b_{1,2,3,4}=\text { Koefisien regresi } \\
& \text { e = error term }
\end{aligned}
$$

\section{Hasil dan Pembahasan Uji Validitas}

Hasil uji validitas dapat dilihat dibawah ini dengan ketentuan jika $r_{\text {hitung }}>r_{\text {tabel }}(0,361)$ atau nilai sig $<0,05$ maka item pernyataan tersebut dianggap valid. Seluruh $r_{\text {hitung }}$ tiap pernyataan memiliki nilai lebih besar dari $r_{\text {tabel }}$ dan seluruh tingkat signifikan pada pernyataanlebih besar dari 0,05 sehingga diperoleh hasil bahwa semua pernyataan dalam kuesioner adalah valid dan layak digunakan dengan nilai tertinggi pada pernyataan ke1 variabel budaya organisasi dengan nilai 0,934 sedangkan nilai terendah pada pernyataan ke 1 variabel disiplin kerja dengan nilai 0,523. Dengan demikian maka kuesioner dapat digunakan untuk melakukan pengecekan terhadap kehandalan kuesioner tersebut atau dilakukan pengujian reliabilitas.

\section{Uji Reliabilitas}

Cara pengukuran reliabilitas adalah seluruh item pernyataan yang telah valid dimasukan dan diukur koefisien Cronbach's Alpha. 
Tabel 1. Uji Reliabilitas Instrumen Pernyataan Variabel $X$ dan $Y$

\begin{tabular}{|l|c|c|}
\hline Variabel & $\begin{array}{c}\text { Cronbach's } \\
\text { Alpha }\end{array}$ & N of Items \\
\hline Kompensasi (X1) & 0,817 & 8 \\
\hline Budaya Organisasi (X2) & 0,935 & 7 \\
\hline Gaya Kepemimpinan (X3) & 0,890 & 6 \\
\hline Disiplin Kerja (X4) & 0,806 & 8 \\
\hline Kepuasan Kerja (Y) & 0,834 & 6 \\
\hline
\end{tabular}

Sumber : Hasil Penelitian, 2020 (Data Diolah)

Berdasarkan tabel diatas, dapat dilihat instrumen dikatakan reliabel karenanilai koefisien cronbach alpha yang diperoleh lebih besar dari 0,6 sehingga jawaban yang diberikan responden dapat dipercaya atau dapat diandalkan.

\section{Uji Normalitas}

Data menyebar disekitar garis diagonal dan mengikuti arah garis diagonal atau grafik histogramnya menunjukkan pola distribusi normal dengan tidak melenceng ke kiri maupun ke kanan dan berbentuk lonceng, maka regresi dianggap memenuhi asumsi normalitas. Pada gambar normal probability plot diatas dapat dilihat bahwa titik-titik mendekati garis diagonal. Hal ini menunjukkan bahwa data berdistribusi normal dan memenuhi asumsi pengujian normalitas. Pada tabel diatas, dapat dilihat bahwa hasil pengujian normalitas Kolmogorov-smirnov membuktikan bahwa nilai tingkat signifikan yang dihasilkan lebih besar dari 0,05 yaitu sebesar 0,726 maka dapat disimpulkan bahwa pengujian statistik normalitas tergolong berdistribusi normal.

\section{Uji Multikolinieritas}

Nilai korelasi untuk variabel kompensasi, budaya organisasi, gaya kepemimpinan dan disiplin kerja mempunyai nilai tolerance yang lebih besar dari 0,10 dan nilai VIF yang lebih kecil dari 10 sehingga dapat disimpulkan bahwa seluruh variabel tidak terdapat adanya gejala multikolinieritas.

\section{Uji Heteroskedastisitas}

Berdasarkan pada tabel di atas, maka dapat dilihat bahwa variabel kompensasi, budaya organisasi, gaya kepemimpinan dan disiplin kerja memiliki nilai tingkat signifikansi yang lebih besar dari 0,05 sehingga dari hasil perhitungan dan tingkat signifikan diatas maka tidak ditemukan adanya terjadi heteroskedastisitas. Pada gambar grafik scatterplot diatas, dapat dilihat bahwa titiktitik menyebar secara acak (random) serta tersebar di atas maupun dibawah angka 0 pada sumbu Y. Hal ini dapat disimpulkan bahwa tidak terjadi heteroskedastisitas.

\section{Analisis Regresi Linier Berganda}

Metode analisis regresi linier berganda digunakan untuk mengetahui pengaruh kompensasi, budaya organisasi, gaya kepemimpinan dan disiplin kerja terhadap kepuasan kerja karyawan.

Tabel 2. Hasil Analisis Regresi Linier Berganda

\begin{tabular}{|l|r|r|r|}
\hline \multirow{2}{*}{ Model } & \multicolumn{2}{|c|}{$\begin{array}{l}\text { Unstandardized } \\
\text { Coefficients }\end{array}$} & $\begin{array}{l}\text { Standardized } \\
\text { Coefficients }\end{array}$ \\
\cline { 2 - 5 } & \multicolumn{1}{|c|}{ B } & \multicolumn{1}{|c|}{$\begin{array}{c}\text { Std. } \\
\text { Error }\end{array}$} & Beta \\
\hline (Constant) &, 05 & 2,244 &, 29 \\
Kompensasi &, 179 &, 048 &, 33 \\
Budaya Organisasi &, 360 &, 08 &, 23 \\
Gaya Kepemimpinan &, 179 &, 050 &, 208 \\
Disiplin Kerja &, 148 &, 050 & \\
\hline
\end{tabular}

Pada tabel diatas, diketahui pada Unstandardized Coefficeints bagian Bdiperoleh persamaan regresi linier berganda yaitu dengan rumus berikut :

$Y=0,052+0,176 X_{1}+0,360 X_{2}+0,175 X_{3}+0,148 X_{4}$

Konstanta $(\alpha)=0,052$ menunjukkan nilai konstanta, jika nilai variabel bebas yaitu kompensasi, budaya organisasi, gaya kepemimpinan dan disiplin kerja bernilai 0 maka kepuasan kerja karyawan adalah tetap sebesar 0,052 . Koefisien $X_{1}\left(b_{1}\right)=0,176$ menunjukkan bahwa variabel kompensasi berpengaruh positif terhadap kepuasan kerja karyawan sebesar 0,176 . Artinya setiap penurunan kompensasi sebesar 1 satuan, maka kepuasan kerja karyawan akan meningkat sebesar 0,176. Koefisien $\mathrm{X}_{2}\left(\mathrm{~b}_{2}\right)=0,360$ menunjukkan bahwa variabel budaya organisasi berpengaruh positif terhadap kepuasan kerja karyawan sebesar 0,360 . Artinya setiap peningkatan budaya organisasi sebesar 1 satuan, maka kepuasan kerja karyawan akan meningkat sebesar 0,360.

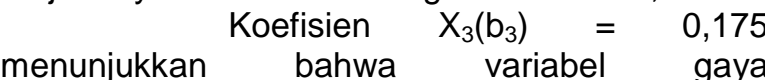
kepemimpinan berpengaruh positif terhadap kepuasan kerja karyawan sebesar 0,175. Artinya setiap peningkatan gaya kepemimpinan sebesar 1 satuan, maka kepuasan kerja karyawan akan meningkat sebesar 0,175 . Koefisien $\mathrm{X}_{4}\left(\mathrm{~b}_{4}\right)=$ 0,148 menunjukkan bahwa variabel disiplin kerja berpengaruh positif terhadap kepuasan kerja karyawan sebesar 0,148. Artinya setiap peningkatan disiplin kerja sebesar 1 satuan, maka kepuasan kerja karyawan akan meningkat sebesar 0,148.

Nilai Adjusted $R$ Square $\left(\mathrm{R}^{2}\right)$ atau koefisien determinasi yang telah terkorelasi dengan jumlah 
variabel dan ukuran sampel sehingga dapat mengurangi unsur bias jika terjadi penambahan variabel maupun penambahan ukuran sampel yang diperoleh adalah sebesar 0,473. Hal ini berarti besarnya pengaruh kompensasi, budaya organisasi, gaya kepemimpinan dan disiplin kerja terhadap kepuasan kerja karyawan adalah sebesar 47,3\% dan sisanya 52,7\% dipengaruhi oleh faktor-faktor lain yang berasaldari luar model penelitian ini seperti deskripsi kerja, karakteristik kerja, prestasi kerja penilaian kinerja, komunikasi, konflik kerja, iklim kerja, stres kerja, promosi jabatan dan variabel lainnya.

\section{Kesimpulan}

1. Kompensasi secara parsial berpengaruh terhadap kepuasan kerja karyawan pada Restoran Sari Laut Nelayan.

2. Budaya organisasi secara parsial berpengaruh terhadap kepuasan kerja karyawan pada Restoran Sari Laut Nelayan.

3. Gaya kepemimpinan secara parsial berpengaruh terhadap kepuasan kerja karyawan pada Restoran Sari Laut Nelayan.

4. Displin kerja secara parsial berpengaruh terhadap kepuasan kerja karyawan pada Restoran Sari Laut Nelayan.

5. Kompensasi, budaya organisasi, gaya kepemimpinan dan disiplin kerja secara simultan berpengaruh terhadap kepuasan kerja karyawan pada Restoran Sari Laut Nelayan.

\section{Daftar Pustaka}

Avif, Noerdi. Ansyah. Dan Agus, Frianto. 2013. Pengaruh Kompensasi, Budaya Organisasi dan Gaya Kepemimpinan Terhadap Kepuasan Kerja Karyawan. Jurnal IImu Manajemen Volume 1 Nomor 4 Juli 2013

Badeni. 2017. Kepemimpinan dan Perilaku Organisasi Edisi Ketiga. Bandung : Alfabeta.

Fahmi, Irfam. 2016. Perilaku Organisasi Teori, Aplikasi dan Kasus. Bandung Alfabeta

Faidillah, Walgito Tarigan. 2018. Pengantar Manajemen Sumber Daya Manusia.Jakarta : Bumi Aksara.

Feriyanto, Suharsimi., Sarwono, Jonathan. 2015. Manajemen Sumber Daya Manusia. Yogyakarta : Graha IImu.

Hamali, Goski. 2018. Manajemen Sumber Daya Manusia (Teori, Konsep dan Penerapan). Malang : UB Press.
Handoko, Hani, T. 2012. Manajemen.Edisi Kedua. Yogyakarta : BPFE Yogyakarta

Hartatik, Meylani Adya. 2017. Manajemen Sumber Daya Manusia Untuk Perusahaan Berkembang. Jakarta : Murai Kencana.

Hasibuan, Malayu S.P. 2016. Manajemen Sumber Daya Manusia Edisi Kesembilan Belas. Jakarta : PT. Bumi Aksara.

Herlina, Vivi. 2019. Panduan Praktis Mengolah Data Kuesioner Menggunakan SPSS. Jakarta : PT. Elex Media Komputindo.

I, Made. Adi. Suryadharma. Dan I, Gede Riana,Desak.Ketut.Sintasih. 2016. Pengaruh Kepemimpinan dan Kompensasi Terhadap Kepuasan Kerja dan Kinerja Karyawan (Studi pada PT. BPR Sri Artha Lestari Denpasar). E- jurnal Ekonomi dan Bisnis Universitas Udayana 5.5 (2016).

Jaya, I Made Laut Mertha Jaya. 2019. Pengolahan Data Kesehatan Dengan SPSS. Penerbit Thema Publishing, Yogyakarta.

Lusigita, Kadek 2017, JAGADHITA : Journal Ekonomi \& Bisnis, Vol 4, No.1 Maret 201

Martoyo, S. 2008. Manajemen Sumber Daya Manusia. Edisi Kelima. Cetakan Pertama. BPFE Yogyakarta

Nitisemito, Alex S, 2002, Manajemen Personalia. Cetakan ke 9. Edisi ke 4 Jakarta : Ghalia Indonesia

Noer, Aisyah. Barlian. SKM, dan MM. 2017. Faktor Determinn Kepemimpinan dan Kepuasann Kerja Karyawan di Klinik Husada Mulia Kabupaten Lumajang Volume. 1 No. 2-Juli 2017.

Noor, Shella. 2018. Manajemen Sumber Daya Manusia. Yogyakarta: Graha IImu. Priyatno, Dwi. 2018. SPSS Panduan Mudah Olah Data Bagi Mahasiswa \&Umum. Yogyakarta : CV. Andi Offset

Putrandi, Muhammad. 2017. Manajemen Personalia dan Sumber Daya Manusia.Jakarta : Ghalia Indonesia.

Robbins. Stephans, 2006. Organization Bahaviour. A Simon \& Schuster Company. Englewood Cliffs. New Jersey 07632

Rumawas, Wehelmina,2013. Pengaruh Kepemimpinan terhadap Kepuasan Kerja

Siagian, Sondang P. 2015. Manajemen Sumber Daya Manusia. Jakarta : Bumi Aksara. 
Sinambela, Lijan Poltak. 2017, Manajemen Sumber Daya Manusia (Membangun Tim Kerja Yang Solid Untuk Meningkatkan Kinerja). Jakarta : Bumi Aksara.

Siregar, Arishanti Casimir. 2018. Manajemen Sumber Daya Manusia (Prosedur Penelitian Suatu Pendekatan Sumber Daya Manusia). Jakarta : Rineka Cipta.

Sunyoto, Danang. 2015. Manajemen Sumber Daya Manusia Edisi Revisi.Yogyakarta : CAPS.

Sutrisno, Sonny. 2016. Manajemen Sumber Daya Manusia Untuk Perusahaan.Bandung : Alfabeta.

Thoha, Miftha. 2015. Manajemen Kepemimpinan. Jakarta : Rajagrafindo Persada

Wahjono, Murtiningsih. 2013. Aplikasi Analisis Multivariete Dengan Program IBM SPSS. Semarang : BP Universitas Diponegoro.

Wahyudi, S. T. 2017. Statistika Ekonomi : Konsep, Teori dan Penerapan.

Penerbit UB Press. Malang.

Wibowo, Hutagaol. 2016. Manajemen Pengelolaan Sumber Daya Manusia. Yogyakarta : CAPS. 